\title{
Self-Efficacy Penderita Hipertensi Di Puskesmas Kota Selatan Gorontalo
}

\author{
Nurdiana Djamaluddin ${ }^{1}$, Ita Sulistiani ${ }^{2}$,Nirwanto K. Rahim ${ }^{3}$, Ahmad Aswad ${ }^{4}$ \\ ${ }^{1,2,3}$ Departemen Keperawatan Medikal Bedah, Program Studi Ilmu Keperawatan, \\ Universitas Negeri Gorontalo \\ ${ }^{4}$ Jurusan Keperawatan, Politekhnik Kemenkes Gorontalo \\ Email: nurdiana@ung.ac.id
}

\begin{abstract}
Abstrak
Prevalensi dan insidensi penyakit hipertensi semakin meningkat dan menyebabkan tingginya morbiditas dan mortalitas yang tinggi. Gorontalo merupakan Provinsi yang ikut menyumbang jumlah kumulatif kasus hipertensi. Sebagai penyakit yang dikenal dengan isitilah "silent killer". Dalam upaya pengurangan komplikasi ini diperlukan kepatuhan dan kesadaran dri akan kemampuan dalam mencapai tujuan pengobatan yang kemudian lebih dikenal dengan isitilah self-efficacy. Rancangan penelitian ini menggunakan deskriptif dimana pengukuran dengan menggambarkan variabel yang diteliti tanpa menganalisa hubungan antar variabel. Sampel yang digunakan dalam penelitian ini yakni purposive sampling dengan jumlah 100 sampel yang diambil berdasarkan kriteria sampel. Hasil peneltian didapatkan terdaat 65 responden berjenis kelamin laki-laki dan 35 responden berjensi kelamin perempuan . Pada penelitian ini juga didapatkan juga responden yang memiliki self-efficacy tinggi berjumlah 53, dan 47responden memiliki self-efficacy rendah. Self-efficacy memberikan kontribusi terhadap pemahaman yang lebih baik dalam proses perubahan perilaku kesehatan sehingga akan meningkatkan kemampuan seseorang dalam memahami terkait penyakit, dan memilih cara yang tepat dalam mengurangi tingkat keparahan dengan keterampilan yang terlatih.
\end{abstract}

Kata kunci:, Hipertensi, self-efficacy

\begin{abstract}
The prevalence and incidence of hypertension are increasing and causing high morbidity and high mortality. Gorontalo is a province that contributes to the cumulative number of hypertension cases. As a disease known as the "silent killer". To reduce these complications, adherence, and awareness of the ability to achieve treatment goals are needed, which is then known as self-efficacy. This research design uses descriptive measurement where the measurement describes the variables studied without analyzing the relationship between variables. The sample used in this study is purposive sampling with a total of 100 samples taken based on sample criteria. The results of the study found that 65 respondents were male and 35 respondents were female. In this study, 53 respondents who had high self-efficacy were also found, and 47 respondents had low self-efficacy. Self-efficacy contributes to a better understanding of the process of health behavior change so that it will increase a person's ability to understand related diseases and choose the right way to reduce the severity with trained skills.
\end{abstract}

Kata kunci:, Hypertension, self-efficacy

\section{Pendahuluan}

Prevalensi dan insisdensi penyakit hipertensi semakin meningkat dan masih mejadi perhatian utama karena morbiditas dan mortalitas yang tinggi. Data World Health Organization (WHO) pada tahun 2015 menunjukkan bahwa terdapat 1.13 miliar orang di dunia menyandang hipertensi angka ini menunjukkan bahwa 1

dari 3 orang di dunia terdiagnosis hipertensi dan diperikirakan setiap tahunnya 10.44 juta orang meninggal akibat hipertensi dan komplikasinya. Peningkatan kasus ini pun terjadi di seluruh dunia termasuk Indonesia. Di Indonesia berdasarkan hasil Riskesdas (2018) prevalensi hipertensi berdasarkan 
diagnosis atau minum obat hipertensi didapatkan jumlah penderita sebanyak 658.201 orang, Gorontalo merupakan salah satu Provinsi yang ikut menyumbangkan angka dalam jumlah kumulatif kasus hipertensi. Berdasarkan hasil data BPS (2018) didapatkan bahwa hipertensi merupakan salah satu penyakit terbanyak yang diderita oleh masyarakat Gorontalo dengan estimasi sebesar 23.317 pada tahun 2015 dan mengalami pengingkatan pada tahun 2018 dengan estimasi penderita sebbnyak 7.116 orang.

Peningkatan ini berdampak pada tingginya kematian dini, stroke dan penyakit jantung di dunia. Sebagai penyakit yang dikenal dengan istilah " silent killer" hanya kurang dari seperlima orang yang terdiagnosis hipertensi yang melakukan upaya terhadap pengendalian tekanan darah yang dimiliki seperti patuh dalam pengobatan , sehingga tidak jarang penderita akan mengalami kematian tibatiba diakibatkan komplikasi dari penyakit hipertensi seperti stroke, gagal ginjal dan ganggan jantung (Kementerian Kesehatan Republik Indonesia, 2019).

Dalam upaya pengurangan komplikasi ini diperlukan kepatuhan dalam pengobatan. Namun seringkali yang terjaid individu tidak patuh dalam pengobatan. Ketidakpatuhan dalam pengobatan menjadi yang paling sering dilaporkan sebagai kegagalan manajemen diri dalam pengendalian tekanan darah pada pasien hipertensi. Ketidakpatuhan terhadap pengobatan merupakan masalah kesehatan global yang pada akhirnya akan meningkatkan resiko hospitalisasi, rehospitalisasi dan kematian dini (American Heart Association, 2014; Jimmy B., Jose J., 2011; Oh, 2021). Sehingga dalam mengurangi resiko komplikasi akibat ketidakpatuhan maka diperlukan upaya dalam internal dari individu untuk mengelola gejala dan akibat dari penyakit kronis seperti pengobatan dan perawatan, aktivitas fisik, aktivitas sosial, dan perubahan gaya hidup, serta keyakinan pasien untuk melakukan perubahan atau penyesuaian perilaku untuk mencapai tujuan pengobatan, yang kemudian istilah ini lebih dikenal dengan selfefficacy(Kauric-Klein, Z., Peters, R. M., \& Yarandi \& H. N., 2017; Peñarrieta, M. I., Flores-Barrios，2015; Warren-findlow \& Huber, 2013)

Self-efficacy adalah kepercayaan seseorang dalam melakukan aktivitas tertentu, termasuk kepercayaan untuk melakukan aktivitas ketika ada hambatan untuk mencapai tujuan tertentu (KauricKlein, Peters, \& Yarandi, 2017). Penelitian yang dialkukan pada tahun 2012 oleh Warren didapatkan bahwa self-efficacy memliki hubungan siignifkan terhadap 
kepatuhan pengobatan, konsumsi diet rendah garam, beradaptasi dengan aktivitas fisik, tidak merokok dan melakukan tekhnik manajamen berat badan. Berdasarkan hasil wawancara yang dilakukan pada 5 pasien yang melakukan kunjungan berobat di puskesmas Dungingi Kota Gorontalo, 3 orang pasien mengaku tidak meminum obat anti-hipertensi saat tidak merasakan adanya keluhan atau tanda penyakit, malas berolahrga, bahkan masih sering memakan makanan bersanta. Mereka khawatir jika terlalu sering minum obat maka akan terjadi ketergantungan minum obat. 2 diantaranya mengaku kadang kupa minum obat karena sibuk bekerja dengan demikian dapat didentifikasikan bahwa keyakian yang dimiiki penderita mengarah pada selfefficacy (keyakinan diri) rendah terhadap pengobatan hipertensi, manajemen diri yang kurang, diaman jika ini berkelanjutan maka akan berpengaruh terhdap kondisi penderita. Berdasarkan hasil ini peneliti tertarik melakukan melakukan penelitian untuk mengkaji terkait self-efficacy pada penderita hipertesnsi di puskesmas Kota Gorontalo.

\section{Metode Penelitian}

Penelitian ini merupakan penelitian deskriptif survey. Kuesioner menggunakan "self efficacy to manage hypertension".

Penelitian ini melibatkan 100 orang responden yang berada di puskesmas kota Gorontalo yang memenuhi kriteria penelitian. Teknik sampling yang digunakan adalah purposive sampling. Analisis univariat digunakan unutk mendeskripsikan karakterisitik responde, dan distribusi responden berdasrkan selfefficacy. Sebelum penelitian seluruh responden akan di jelaskan tentang mekanisme penelitian dan mengisi informed concent. Setelah di melakukan pengisian informed concent dan kuesioner seluruh responden diberikan penjelasan tentang produksi ASI.

\section{Hasil Penelitian}

Sebanyak 100 responden telah memenuhi kriteria penelitian. Hasil penelitian disajikan dalam bentuk table distirbusi

Tabel 1. Dsitribusi frekuensi dari karakteristik responden berdasarkan jenis kelamin dan self-efficacy

\begin{tabular}{cc} 
Karakteristik & \multicolumn{2}{c}{\begin{tabular}{c}
$(\mathrm{n}=100)$ \\
\cline { 2 - 3 }
\end{tabular}} \\
\cline { 2 - 3 }
\end{tabular}
Jenis kelamin

$\begin{array}{lll}\text { Pria } & 65 & 65\end{array}$

Wanita $\quad 35 \quad 35$

Self-efficacy $\quad 53 \quad 53$

Self Efficacy tinggi

$\begin{array}{lll}\text { Self-Efficacy rendah } & 47 & 47\end{array}$

\section{Pembahasan}

Hasil penelitian ini juga menunjukkan bahwa jenis kelamin laki-laki lebih banyak menderita hipertensi dibandingkan jenis kelamin perempuan. 
Hasil ini sejalan dengan penelitian yang dilakukan Everet dan Zajacova (2015) yang menjukkan bahwa laki-laki lebih memiliki tingkat hipertensi lebih tinggi daripada perempuan. Jenis kelamin merupakan salah satu faktor yang memepengaruhi tekanan darah yang tidak dapat diubah. Hasil ini didukung juga hasil yang didapatkam oleh Prasetyaningrum (2014) yang mengatakan bahwa laki-laki lebih beresiko mengalami hipertensi dibandingan perempuan saat usia $<45$ tahun, tetapi saat usia > 65 tahun perempuan lebih beresiko mengalami hipertensi dibandingkan dengan laki-laki diakibatkan wanita memasuki masa menopasuse. Peningkatan resiko hiperensi ini berkaitan dengan faktor resiko usia yang dihubungkan dengan peningkatan peripbrelar vascular resistance (hambatan aliran darah dalam pmbulih darah perifer ) dalam arteri (Benson 2006).

Pria sering mengalami tanda-tanda hipertensi pada usia akhir tiga puluhan, sedangkan wanita sering mengalami hipertensi setelah menopause. Hasil ini tidak sejalan dengan penelitian yang dilakukan oleh Miftahul (2019) yang menjelaskan bahwa wanita memiliki peluang sebanyak 2.7 kali untuk terkena hipertensi dibandingkan dengan responden berjenis kelamin laki-laki. Wanita yang mengalami menopause merupakan salah satu faktor yang mempengaruhi kecederungan angka kejadian hieprtensi lebih tinggi daripada laki-laki. Hal ini dikarenakan perempuan yang telah mengalami menopause memilki kadar estrogen yang rendah/ Sedangkan estrgen berfungsi untuk menigkatkan Highh density Lipoprotein(HDL) yang sangat berpedan dalam menjaga kesehatan pembuluh darah.

Dalam penelitian ini didapatkan 53 atau sekitar $52 \%$ responden memiliki selfefficacy tinggi. Hal ini sesuai dengan penelitian yang dilakukan oleh Okatiranti et al (2017), bahwa lebih dari setengah responden memiliki self-efficacy yang tinggi. Hal tersebut menunjukkan bahwa semakin tinggi Self-efficacy individu maka akan semakin baik perawatan dirinya.

Bandura (1997) mendefinisikan self efficacy adalah suatu keyakinan seseorang akan kemampuannya untuk mengatur dan melaksanakan serangkaian tindakan yang diperlukan untuk menyelesaikan suatu tugas tertentu. Perawatan diri yang efektif berarti individu memiliki rasa tanggung jawab pada dirinya dalam menjaga kesehatan dirinya sendiri (Nwine, 2011).

Faktor utama dalam meningkatkan kesehatan yaitu dengan melakukan perawatan diri. Dalam menjalankan perawatan diri tersebut dalam diri individu 
diperlukan Self Efficacy. Self Efficacy merupakan faktor utama yang mempengaruhi perawatan diri bagi penderita penyakit kronis $(\mathrm{Hu} \&$ Arou, 2013). Sejalan dengan hasil penelitian Oktarianti et al. (2017), menyatakan bahwa ada hubungan antara self-efficacy dengan perawatan diri lansia hipertensi sehingga lansia dapat melakukan perawatan diri.

Menurut Ogedegbege (2003), Keyakinan tentang self-efficacy akan memberikan dasar motivasi, kesejahteraan dan prestasi seseorang. Self efficacy akan menentukan bagaimana seseorang merasa, berfikir, memotivasi dirinya dan berperilaku. Self efficacy dianggap sebagai prediktor yang paling menonjol untuk perubahan perilaku kesehatan seperti kepatuhan terhadap pengobatan pada pasien dengan penyakit kronis, salah satunya hipertensi.

Self-efficacy yang berbeda-beda pada pasien hipertensi disebabkan oleh perbedaan proses self-efficacy yang dijalani oleh s pasien hieprtensi. Tsang, hui \& law (2012) menjelaskan bahwa terdapat empat proses self-efficacy yaitu proses kognitif , motivasi, efektif dan seleksi dan merupakan suatu proses yang berkesinambungan. Sebagian besar responden berdasarkan hasil kuesioner dan wawancara didapatkan mempunyai kualitas pengalaman yang kurang baik terutama dalam penyesuaian pola hidup sehingga responden tidak termotivasi untuk mengontrol tekanan darah.

Arsyita (2016) menjelaskan bahwa seseorang dengan sellf-efficacy tinggi memiliki anggapan bahwa dirinya mampu menggunakan kemampuannya untuk mencapai suatu hasil yang baik. Selfefficacy memberikan kontribusi terhadap pemahaman yang lebih baik dalam proses perubahan perilaku kesehatan sehingga akan meningkatkan kemampuan seseorang dalam memahami terkait penyakit, dan memilih cara yang tepat dalam mengurangi tingkat keparahan dengan keterampilan yang terlatih.

\section{Simpulan}

Self-efficacy memberikan kontribusi terhadap pemahaman yang lebih baik dalam proses perubahan perilaku kesehatan sehingga akan meningkatkan kemampuan seseorang dalam memahami terkait penyakit, dan memilih cara yang tepat dalam mengurangi tingkat keparahan dengan keterampilan yang terlatih

\section{Daftar Pustaka}

American Heart Association. (2014). FACT SHEET: A Tough Pill to Swallow: Medication Adherence and Heart Disease. Retrieved from www.heart.org

Benson Herbert, 2006, Menurunkan 
Tekanan Darah, Pt Bhuana Ilmu Popular: Jakarta Dinas Kesehatan Kota Pal

BPS. (2018). Jumlah Kasus 10 Penyakit Terbanyak di Provinsi Gorontalo, 2015-2016. Retrieved from https://gorontalo.bps.go.id/statictable/ 2016/08/23/436/jumlah-kasus-10penyakit-terbanyak-di-provinsigorontalo-2015-2016.html

Di, H., Ranotana, P., Kawulusan, K. B., Katuuk, M. E., \& Bataha, Y. B. (2019). HUBUNGAN SELF-EFFICACY DENGAN KEPATUHAN MINUM OBAT KOTA MANADO, 7, 1-9.

Everett \& Zajacova. 2015. Gender differences in hypertension and hypertension awareness among young adults. Biodemography and social biology, 61(1), 1-17.

Fatmawati, B. R., \& Suprayitna, M. (2021). Self efficacy dan perilaku sehat dalam modifikasi gaya hidup penderita hipertensi, 11(1), 1-7.

Jimmy B., Jose J. (2011). Patient Medication Adherence: Measure In Daily Practice. Oman Medical Journal., 26(3), 155-159. https://doi.org/DOI 10.5001/omj.2011.38.

Kauric-Klein, Z., Peters, R. M., \& Yarandi, \& H. N. (2017). elf-efficacy and blood pressure self-care behaviors in patients on chronic hemodialysis. Western Journal of Nursing Research, 39(7).

Kementerian Kesehatan Republik Indonesia. (2018). Laporan nasional RISKESDAS 2018. Retrieved from http://labdata.litbang.kemkes.go.id/im ages/download/laporan/RKD/2018/La poran_Nasional_RKD2018_FINAL.p df

Kementerian Kesehatan Republik Indonesia. (2019). Hipertensi Si Pembunuh Senyap. Retrieved from https://pusdatin.kemkes.go.id/resource s/download/pusdatin/infodatin/infodat in-hipertensi-si-pembunuh-senyap.pdf
Kendu, Y. M., Qodir, A., \& Apryanto, F. (2021). HUBUNGAN SELFEFFICACY DENGAN TINGKAT KEPATUHAN MINUM OBAT, 2, 13-21.

Oh, S. (2021). Medication Adherence and Effective Management of Hypertension, 89-90.

Oka, P., Nurhesti, Y., \& Manangkot, M. (1980). Hubungan self-efficacy dengan self-management behaviour pada pasien hipertensi, 8(April 2020), 65-72.

Peñarrieta, M. I., Flores-Barrios, F., Gutiérrez-Gómez, T., PiñonesMartínez, S., ResendizGonzalez, E., \& \& María QuinteroValle, L. (2015). Self-management and family support in chronic diseases. Journal of Nursing Education and Practice, 5(11).

Prasetyaningrum. 2014. Hipertensi bukan untuk ditakuti, Jakarta .Fmedia (Imprint Agro Media Pustaka).

Self, H., Dengan, E., Focused, P., \& Pada, C. (2020). The relationship of selfefficacy with problem focused coping in hypertensive patients, 7(1), 1-8.

Sinaga, J., \& Sembiring, E. (2018). Self Efficacy dan Gaya Hidup Pasien Hipertensi, 9(November), 360-365.

Warren-Findlow, J., Seymour, R. B., \&, \& Huber, L. R. B. (2012). The association between self-efficacy and hypertension self-care activities among African American adults. Journal of Community Health, 37(1).

Warren-findlow, J., \& Huber, L. R. B. (2013). NIH Public Access, 37(1), 1524. https://doi.org/10.1007/s10900011-9410-6.The

Widiawatie, N., Handayani, F., Sobirin, M. A., \& Widiawatie, N. (2021). Factors affecting self-efficacy against hypertension self-care in hypertension patients : a scoping review, 9(3), 914922. 